\title{
Early and one year results of transvascular pulmonary valve implantation in patients after tetralogy of Fallot, Ross and Rastelli operations
}

Wczesne i roczne wyniki zabiegów przeznaczyniowego wszczepienia zastawki płucnej u chorych po korekcji tetralogii Fallota oraz operacjach Rossa i Rastelliego

\author{
Elżbieta K. Biernacka', Marcin Demkow ${ }^{2}$, Mateusz Śpiewak ${ }^{2,3}$, Lars Šrndergaard ${ }^{4}$, Mirosław Kowalski', \\ Hanna Siudalska ${ }^{5}$, Piotr Wolski ${ }^{6}$, Jolanta Miśko ${ }^{3}$, Piotr Hoffman ${ }^{1}$, Witold Rużyłło ${ }^{2}$ \\ 1 Department of Congenital Heart Defects, Institute of Cardiology, Warsaw, Poland \\ 2 Department of Coronary Artery and Structural Heart Diseases, Institute of Cardiology, Warsaw, Poland \\ ${ }^{3}$ Cardiovascular Magnetic Resonance Unit, Institute of Cardiology, Warsaw, Poland \\ 4 Rigshospitalet, Kardiologisk Klinik B, Copenhagen, Denmark \\ ${ }^{5} 1^{\text {st }}$ Department of Cardiosurgery, Institute of Cardiology, Warsaw, Poland \\ ${ }^{6}$ Anaestesiology Department, Institute of Cardiology, Warsaw, Poland
}

Post Kardiol Interw 2010; 6, 3 (21): 104-111 DOI: $10.5114 /$ pwki.2010.16350

\begin{abstract}
Background: Transcatheter pulmonary artery valve implantation (TPVI) is a relatively new method of treatment in patients (pts) after repair of congenital heart disease (CHD).

Aim: To assess the early and one year results of TPVI in patients with right ventricular outflow tract conduit dysfunction.

Material and methods: TPVI with routine pre-stenting with BMS was performed in 17 pts ( 9 men, mean age $24.1 \pm 5.6$ years) for pulmonary conduit dysfunction $11.4 \pm 6.4$ years after total repair of tetralogy of Fallot or pulmonary atresia (11 pts: 8 pts with pulmonary homograft, 3 pts with Contegra xenograft or aortic monocusp homograft), pulmonary stenosis (1 pt), Ross procedure (3 pts) and Rastelli operation (TGA, pulmonary atresia -2 pts). The schedule of follow-up assessment comprised clinical evaluation, cardiovascular magnetic resonance, transthoracic echocardiography and chest X-ray to screen for device integrity. Seventeen pts completed 1-month, 11 pts 6-month and 10 pts 12 -month follow-up.

Results: TPVI was performed with no serious complications in all patients. In 15 patients with significant pulmonary stenosis peak right ventricular outflow tract (RVOT) gradient was reduced from a mean of $73.4 \pm 30.0 \mathrm{~mm} \mathrm{Hg}$ to $35,3 \pm 14,7 \mathrm{~mm} \mathrm{Hg}$ on the next day after implantation $(\mathrm{p}<0.001)$. At 1-month, 6-month and 12-month follow-up mean RVOT gradient was $30.4 \pm 11.2 \mathrm{~mm} \mathrm{Hg}$, $31.1 \pm 11.9$ and $32.7 \pm 11.7 \mathrm{~mm} \mathrm{Hg}$, respectively (NS). In all patients pulmonary valve competence was restored. Mean pulmonary regurgitation fraction decreased from $20.9 \pm 7.8 \%$ to $2.4 \pm 2.1 \%$ ( $p=0.0001)$ one month after procedure and the effect was stable after one year observation. Significant decrease in right ventricular end-diastolic and end-systolic volumes $\left(131.8 \pm 47.8 \mathrm{ml} / \mathrm{m}^{2}\right.$ to $115.3 \pm 40.3 \mathrm{ml} / \mathrm{m}^{2} ; p=0.002$ and $73.1 \pm 41.1 \mathrm{ml} / \mathrm{m}^{2} \mathrm{vs} .57,6 \pm 39,0 \mathrm{ml} / \mathrm{m}^{2} ; p=0.004$, respectively) as well as a slight improvement in RV ejection fraction ( $47.9 \pm 13.0 \%$ to $53.2 \pm 15.2 \%$; $p=0.07$ ) were observed one month after procedure. No stent fractures were seen.

Conclusions:

1. TPVI is an effective and safe method of non-surgical treatment for patients with RVOT conduit dysfunction.

2. TPVI wit the use of pre-stenting technique may be performed in selected patients with RVOT patch.

3. Routine pre-stenting with BMS may protect against stent fractures after TPVI.

4. The study showed excellent results in 10 patients after one-year follow-up.
\end{abstract}

Key words: pulmonary valve, homograft, transvascular implantation, congenital heart diseases

Adres do korespondencji/Corresponding author:

Elżbieta Katarzyna Biernacka MD, PhD, Klinika Wad Wrodzonych Serca, Instytut Kardiologii, ul. Alpejska 42, 04-628 Warszawa, tel.: +48 223434634 , e-mail: kbiernacka@ikard.pl

Praca wpłynęła 15.08.2010, przyjęta do druku 3.09.2010. 


\section{Streszczenie}

Wstęp: Zabieg przeznaczyniowego wszczepienia zastawki płucnej (TPVI) jest stosunkowo nową metodą leczenia chorych po operacyjnej korekcji wady wrodzonej serca.

Cel: Ocena wczesnych i rocznych wyników zabiegów TPVI u chorych ze zwężeniem i/lub niedomykalnością płucną po operacyjnej korekcji wady wrodzonej serca.

Materiał i metody: Przeznaczyniowe wszczepienie zastawki płucnej poprzedzone wszczepieniem metalowego stentu (BMS) wykonano u 17 chorych. Badaną grupę stanowiło 17 pacjentów (9 mężczyzn) w wieku 24,1 $\pm 5,6$ roku, będących 11,4 $\pm 6,4$ roku po operacjach korekcji wad serca z rekonstrukcją drogi odpływu prawej komory: 11 chorych po korekcji całkowitej tetralogii Fallota lub atrezji płucnej (homograft płucny - 8, ksenograft Contegra lub łata przezpierścieniowa z zastawką aortalną monocusp - 3), jedna chora ze zwężeniem zastawki płucnej, 3 - po operacji Rossa i 3 - po operacji Rastelliego (TGA - 1, atrezja płucna - 2). Badania kontrolne obejmowały badanie podmiotowe i przedmiotowe, echokardiogram, zdjęcie RTG klatki piersiowej oraz rezonans magnetyczny serca. Uzyskano obserwacje po jednym miesiącu u 17 chorych, po 6 miesiącach - u 11 i po roku- u 10 osób.

Wyniki: U wszystkich pacjentów wykonano bez powikłań skuteczny zabieg TPVI. Maksymalny gradient płucny u 15 chorych z istotnym zwężeniem drogi odpływu prawej komory obniżył się z 73,4 $\pm 30,0 \mathrm{~mm} \mathrm{Hg}$ do 35,3 $\pm 14,7 \mathrm{~mm} \mathrm{Hg}$ w pierwszej dobie po zabiegu ( $p<0,001)$. Po miesiącu, 6 miesiącach i roku obserwacji gradient płucny wynosit średnio odpowiednio 30,4 $\pm 11,2 \mathrm{~mm} \mathrm{Hg}, 31,1 \pm 11,9 \mathrm{~mm} \mathrm{Hg}$ oraz $32,7 \pm 11,7 \mathrm{~mm} \mathrm{Hg}$ (NS). U żadnego chorego po zabiegu nie obserwowano istotnej fali zwrotnej płucnej. Frakcja niedomykalności płucnej spadła z 20,9 $\pm 7,8 \%$ do $2,4 \pm 2,1 \%$ ( $p=0,0001$ ) po jednym miesiącu i pozostała na tym samym poziomie rok po zabiegu. W całej grupie obserwowano zmniejszenie objętości końcoworozkurczowej oraz końcowoskurczowej prawej komory (odpowiednio z 131,8 $\pm 47,8 \mathrm{ml} / \mathrm{m}^{2}$ do $115,3 \pm 40,3 \mathrm{ml} / \mathrm{m}^{2} ; p=0,002$ oraz $73,1 \pm 41,1 \mathrm{ml} / \mathrm{m}^{2}$ vs $57,6 \pm 39,0 \mathrm{ml} / \mathrm{m}^{2} ; p=0,004$ ) oraz nieznaczne zwiększenie frakcji wyrzutu prawej komory (z 47,9 $\pm 13,0 \%$ do $53,2 \pm 15,2 \%$; $p=0,07$ ) miesiąc po zabiegu. Nie obserwowano złamania stentu zastawki.

Wnioski:

1. Przeznaczyniowe wszczepienie zastawki płucnej jest skuteczną i bezpieczną metodą leczenia dysfunkcji homograftu płucnego.

2. TPVI może być przeprowadzone u wybranych pacjentów, u których rekonstrukcję drogi odpływu prawej komory wykonano za pomocą łaty przezpierścieniowej.

3. Rutynowe wszczepienie BMS do drogi odpływu prawej komory przed TPVI może zapobiegać złamaniom stentu zastawki.

4. Badanie pokazało bardzo dobre wyniki zabiegów TPVI w obserwacjach rocznych.

Słowa kluczowe: zastawka płucna, homograft, przeznaczyniowe wszczepienie zastawki, wrodzone wady serca

\section{Introduction}

Transvascular pulmonary valve implantation (TPVI) is a new treatment option for patients with right ventricular outflow tract (RVOT) dysfunction after congenital heart defects (CHD) surgery [1-5]. Due to remarkable progress in surgical management $85 \%$ patients with $\mathrm{CHD}$ reach adulthood [6-10]. The major problem of this growing population is dysfunction of RVOT regardless of the reconstruction method. The life span of RVOT conduits is limited; consequently, patients may have to undergo multiple re-operations over their lifetime [11-14]. Although relatively safe, re-interventions are associated with significant morbidity. The optimal timing and clinical indications for the surgical treatment are subject to ongoing discussions, because there are no unifying guidelines. Right ventricular outflow tract dysfunction, having deleterious effect on the right ventricular function, is well tolerated for a long time, therefore the decision about re-intervention is frequently made when RV damage becomes irreversible [11-16].

Transvascular pulmonary valve implantation, as less invasive, is an attractive alternative to conduit replacement, particularly for young active people, giving them a chance to come back to their school or work activity within few days after the procedure $[4,5]$.

Since being introduced by Bonhoeffer in 2000 [1], TPVI has been implemented in several centers, however, as a relatively new treatment option, needs further evidence of its efficacy and safety.

\section{Material and methods}

\section{Patients}

The study group comprised 17 consecutive patients ( 9 men, mean age $24.1 \pm 5.6$ years) with repaired CHD (total correction of tetralogy of Fallot, pulmonary atresia, Rastelli operation for pulmonary stenosis and TGA, Ross operation for aortic stenosis), who underwent TPVI with the use of the Melody valve (Medtronic, Inc. Minneapolis, USA) between December 2008 and April 2010. Clinical data are presented in table 1. Mean time since last surgical intervention was $11.4 \pm 6.4$ years. Fifteen (88\%) patients underwent $>1$ (1-4) invasive procedures in history. The mean number of previous invasive procedures in the whole group was $2.5 \pm 0.9$. Indications for the procedure were as follows: predominat RVOT obstruction in 5 patients, predominat PR in 1 patient and mixed lesions in 11 cases. Right ventricle to pulmonary artery (RV-to-PA) gradient in 15 pts with RVOT obstruction (in one case Doppler measurements were unavailable) ranged from 40-122, mean $73.4 \pm 30.0 \mathrm{~mm} \mathrm{Hg}$. In 9 patients who completed preimplantation CMR study mean pulmonary regurgitation fraction was $20.9 \pm 7.8 \%$. All patients but one, who was asymptomatic, reported mild (NYHA class II - 14 pts) or marked limitation of physical activity (NYHA III - 2 pts).

The protocol of valve implantation was approved by the local ethics committee. Each patient signed informed consent for the procedure of valve implantation and CMR study. 
Table 1. Baseline characteristics of the study population

Tabela 1. Charakterystyka badanej grupy

\begin{tabular}{|c|c|}
\hline Age [years] (mean, SD) & $14-31(24.1 \pm 5.6)$ \\
\hline Males, n (\%) & $9(53)$ \\
\hline $\begin{array}{l}\text { Primary diagnosis } \\
\text { tetralogy of Fallot, } \mathrm{n}(\%) \\
\text { pulmonary atresia, VSD, n (\%) } \\
\text { pulmonary stenosis, n (\%) } \\
\text { aortic valve disease (Ross procedure), n (\%) } \\
\text { TGA, VSD, PS, n (\%) }\end{array}$ & $\begin{array}{l}7(41) \\
5(29) \\
1(6) \\
3(18) \\
1(6)\end{array}$ \\
\hline $\begin{array}{l}\text { RVOT type } \\
\text { homograft, n (\%) } \\
\text { other RVOT reconstructions (Contegra } \\
\text { xenograft, aortic monocusp valve), n (\%) }\end{array}$ & $\begin{array}{c}14(82) \\
3(18)\end{array}$ \\
\hline Homograft size $[\mathrm{mm}]$ & $22.1 \pm 2.6$ \\
\hline Homograft calcifications, n (\%) & $12(71)$ \\
\hline Open heart surgeries & $2.2 \pm 0.8$ \\
\hline Percutaneous interventions & $0.2 \pm 0.4$ \\
\hline Time since last surgical intervention [years] & $11.4 \pm 6.4$ \\
\hline $\begin{array}{l}\text { Primary indication for TPVI } \\
\text { pulmonary stenosis, } \mathrm{n}(\%) \\
\text { pulmonary regurgitation, n (\%) }\end{array}$ & $\begin{array}{c}5(30) \\
1(6)\end{array}$ \\
\hline Combined lesions, n (\%) & $11(64)$ \\
\hline
\end{tabular}

VSD - ventricular septal defect, TGA - transposition of great arteries, PS - pulmonary stenosis, RVOT - right ventricular outflow tract, TPVI - transvascular pulmonary valve implantation

VSD - ubytek przegrody międzykomorowej, TGA - przełożenie dużych naczyń, PS - zwężenie zastawki płucnej, RVOT - droga odptywu prawej komory, TPVI - przeznaczyniowe wszczepienie zastawki płucnej

Table 2. Indications for transvascular pulmonary valve implantation based on surgical indications for right ventricular outflow tract revision

Tabela 2. Wskazania do przeznaczyniowego wszczepienia zastawki płucnej na podstawie wskazania do interwencji chirurgicznej

\begin{tabular}{lcc}
\hline Patients & Pulmonary regurgitation & RVOT obstruction \\
\hline Symptomatic & moderate to severe & $\begin{array}{c}\text { RV systolic pressures } \\
\text { exceeding 2/3 of systemic }\end{array}$ \\
\hline Asymptomatic & $\begin{array}{c}\text { RV dilatation, poor RV } \\
\text { function and impaired } \\
\text { exercise tolerance }\end{array}$ & $\begin{array}{c}\text { RV pressure greater } \\
\text { than 3/4 of systemic }\end{array}$ \\
&
\end{tabular}

RV - right ventricle, RVOT - right ventricle outflow tract $R V$ - prawa komora, RVOT - droga odptywu prawej komory

\section{Methods}

Patients were selected on the basis of non-invasive screening including clinical assessment, transthoracic echocardiography and cardiac magnetic resonance (CMR) with contrast enhanced angiography. Indications for TPVI were based on surgical indications for RVOT revision and recommendations of the manufacturer $[17,18]$ (tab. 2). Clinical criteria included symptomatic moderate to severe pulmonary regurgitation (PR) and/or RVOT obstruction with RV systolic pressures exceeding 2/3 of systemic. RV dilatation, poor RV function and impaired exercise tolerance were indications in asymptomatic patients with significant PR; RV pressure greater than 3/4 of systemic in asymptomatic individuals with RVOT obstruction.

Morphological criteria included the current diameter of RVOT conduit $<22 \mathrm{~mm}$ providing suitable anchoring site for the Melody valve. Most patients $(n=14)$ had a full pulmonary homograft with a diameter of $\geq 18 \mathrm{~mm}(18-24 \mathrm{~mm}$ ) when originally implanted. In 3 cases RVOT reconstruction was done using Contegra xenograft $(n=1)$ and RVOT patch (aortic monocusp valve) $(n=2)$.

\section{Echocardiography}

Transthoracic echocardiography was performed with a commercially available echocardiographic system (Vivid 7, GE Medical Systems, Milwaukee, USA). Maximal flow velocity across RVOT was assessed with the use of continuous wave Doppler and peak instantaneous RVOT gradient was calculated with the Bernoulli equation. Pulmonary regurgitation was graded on the basis of colour flow mapping of the RVOT and branch pulmonary arteries as none, trivial, mild, moderate and severe.

\section{Cardiac magnetic resonance}

All patients underwent CMR on a 1.5 T scanner (Avanto, Siemens, Erlangen, Germany). In addition to cine steady state free precession images in left ventricular (LV) long axis (2-chamber, 3-chamber and 4-chamber views), a stack of short axis cross-sectional views covering the entire ventricles from base to the apex and phase contrast flow assessment in the main pulmonary artery (homograft) were performed as previously described $[19,20]$. Right ventricular and LV size and function were analysed with the use of dedicated software (MASS 6.2.1, Medis, Leiden, Netherlands) after manual determination of enddiastolic and end-systolic endocardial outline. All volume measurements were indexed for body surface area and expressed in $\mathrm{ml} / \mathrm{m}^{2}$. Semi-automated vessel edge detection algorithm with manual contour correction (Argus, Siemens, Erlangen, Germany) was used for flow analysis. Pulmonary regurgitation fraction (PRF) was calculated as a ratio of reverse flow over forward flow. Contrast enhanced magnetic resonance angiography with the use of gadolinium contrast agent (Gadovist, Schering, Berlin, Germany) aided demonstration of conduit shape and size. Additionally, free-breathing navigator-gated coronary magnetic resonance angiography was performed to assess relation between coronary arteries and homograft.

\section{Procedure}

Cardiac catheterisation and TPVI were performed under general anaesthesia as previously described [2, 3]. Routine 
pre-stenting of the target site with BMS (IntraStent Max LD, ev3 Endovascular, Plymouth, USA) was used. Coronary angiography with simultaneous balloon inflation at the target implantation site was performed in patients selected on the basis of CMR findings to avoid coronary artery compression during valve implantation [21]. Valved stent diameter was measured at the narrowest site with the balloon fully inflated and after balloon deflation. Stent recoil was defined as the diameter with the balloon fully expanded exceeding by $\geq 1 \mathrm{~mm}$ diameter after balloon deflation. Homograft calcifications were assessed in pre-procedural chest X-rays and in fluoroscopy images during the implantation.

\section{Follow-up}

The schedule of follow-up assessment comprised clinical evaluation, cardiovascular magnetic resonance (CMR), transthoracic echocardiography, cardiopulmonary exercise, and chest $X$-ray to screen for device integrity. Seventeen patients completed 1-month, 11 pts - 6-month and 10 pts - 12-month follow-up.

\section{Statistical analysis}

Unless specified otherwise, continuous variables are presented as means \pm standard deviation. Normality was tested with the use of Kolmogorov-Smirnow test.
Categorical variables are presented as numbers and percentages. Continuous variables before and after TPVI were compared with the use of paired Student's t-test or Wilcoxon rank-sum test as appropriate. For comparisons between peak gradients across RVOT before and after TPVI repeated measures analysis of variance (ANOVA) with Bonferroni correction for post hoc testing was used. All tests were two sided and $p$ value $<0.05$ was considered statistically significant. All statistical analyses were performed with the use of MedCalc 10.0.2.0 statistical software (MedCalc, Mariakerke, Belgium).

\section{Results}

\section{Procedural results}

Transvascular pulmonary valve implantation was successfully performed in all patients without complications. The duration of the procedure ranged from 60 to 180 (mean $136 \pm 31$ ) min. The mean fluoroscopy duration was $26 \pm 11 \mathrm{~min}$ (range: $12-31 \mathrm{~min}$ ). Valved stent recoil was observed in 3 patients. In one patient measurements of stent diameter before and after balloon deflation were not possible due to technical issues.

Transient fever with no signs and symptoms of infection was observed in 11 (65\%) patients. It resolved completely with no additional therapy. All patients were
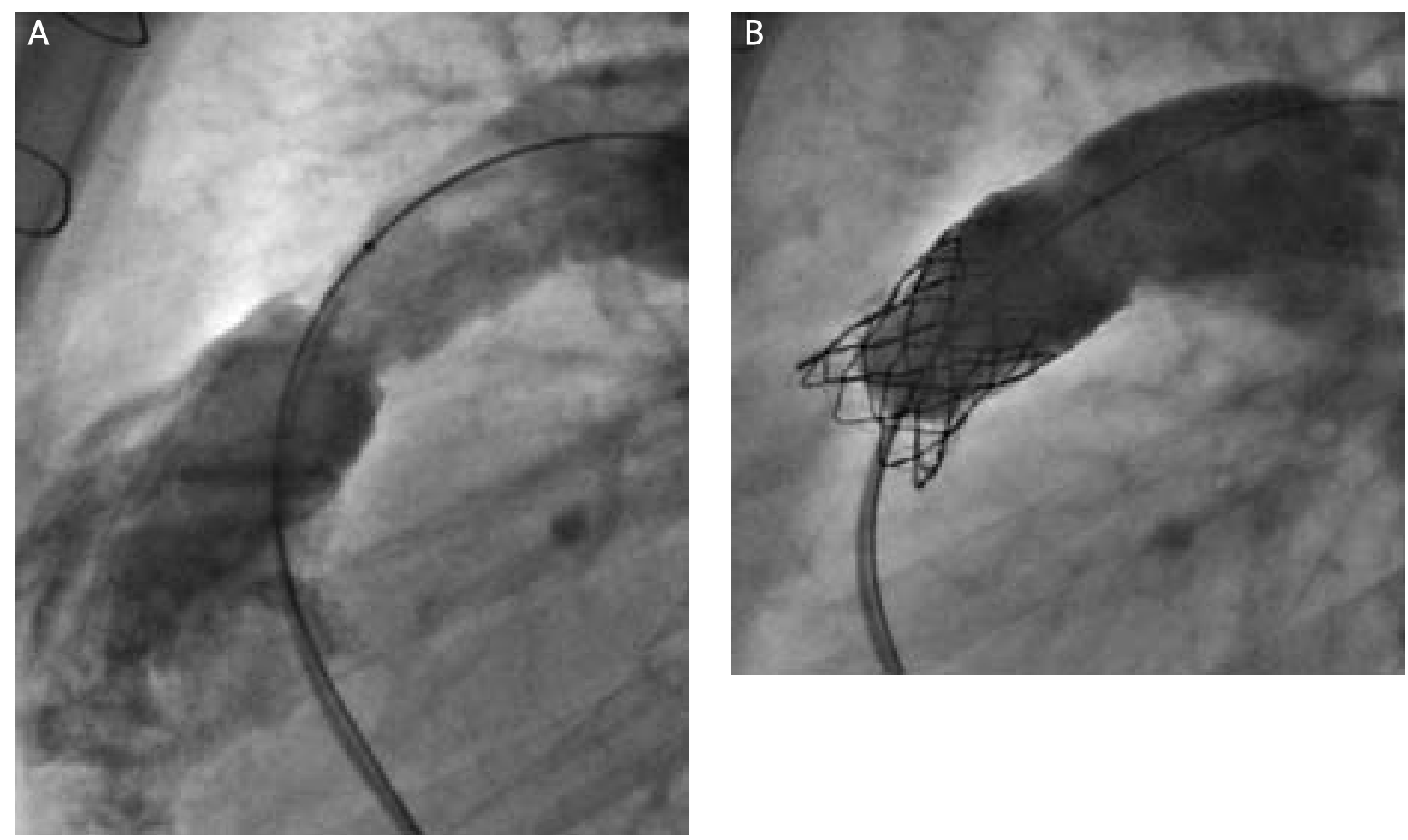

Fig. 1. Pulmonary angiogram (left lateral projection). A - severe pulmonary valve incompetence (contrast injection above the valve), B - after Melody valve implantation. Right ventricular outflow widely open, no valve regurgitation Ryc. 1. Angiografia płucna (projekcja lewo-boczna). A - duża niedomykalność zastawki płucnej (kontrast wstrzyknięty powyżej zastawki), B - po zabiegu wszczepienia zastawki Melody. Szeroka droga odpływu prawej komory bez niedomykalności płucnej 
A

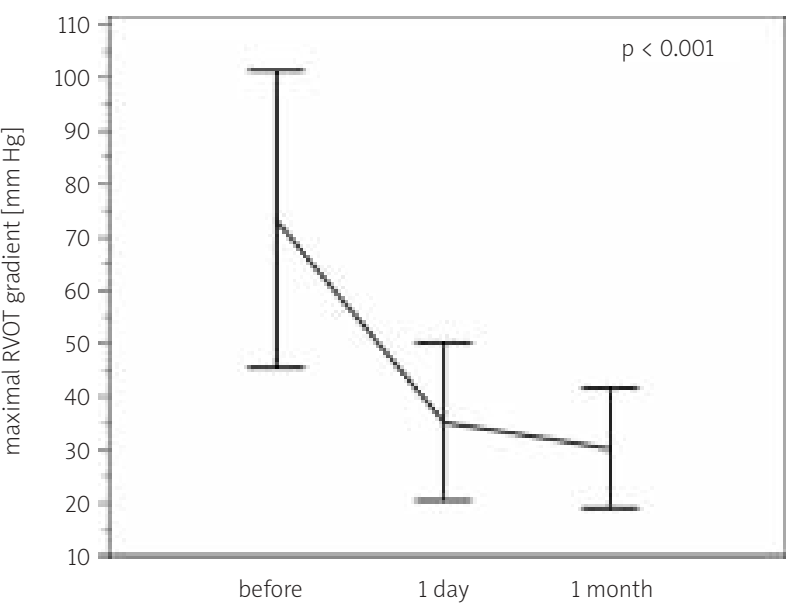

B

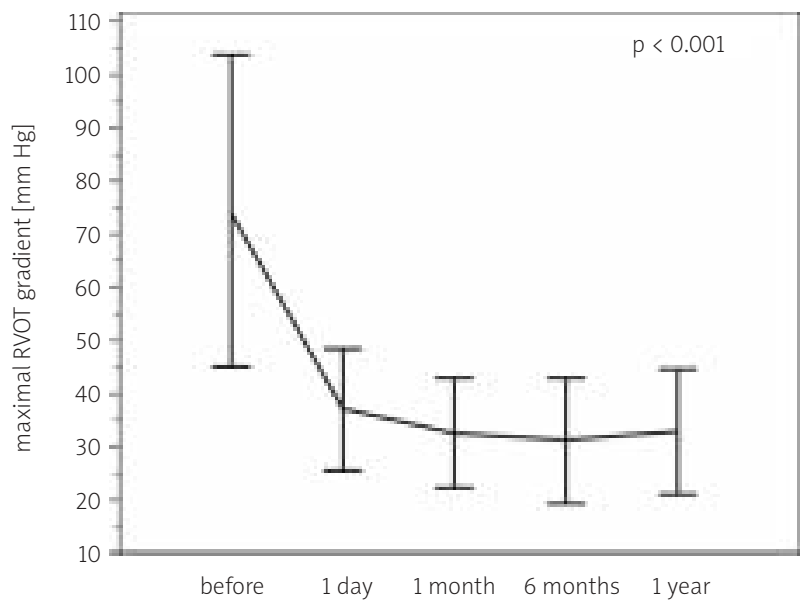

Fig. 2. Peak right ventricular outflow tract (RVOT) gradient. A - before, one day and one month after pulmonary valve implantation; $\mathrm{B}$ - before, one day, one month, 6 months and one year after pulmonary valve implantation (10 pts). Error bars represent standard deviation

Ryc. 2. Maksymalny gradient $w$ drodze odptywu prawej komory (RVOT). A-przed zabiegiem, w pierwszej dobie i miesią po zabiegu wszczepienia zastawki płucnej; B - przed zabiegiem oraz w pierwszej dobie, po 6 miesiacach i po roku od wszczepienia zastawki płucnej (10 chorych). Wykres przedstawia wartości średnie i odchylenie standardowe

mobilised next day after the procedure. Mean hospital stay after the procedure was $86 \pm 28 \mathrm{~h}$.

In all patients with significant RVOT obstruction $(n=16)$ significant decrease of peak RVOT gradient $(35.3 \pm 14.7 \mathrm{~mm} \mathrm{Hg}$ ) was observed on the next day after TPVI ( $p<0.001$, fig. 2. A). In one patient with no significant pre-procedural pulmonary stenosis peak RV-to-PA gradient remained low after valve implantation. Pulmonary valve competence was restored in all patients (fig. 3). Mild PR

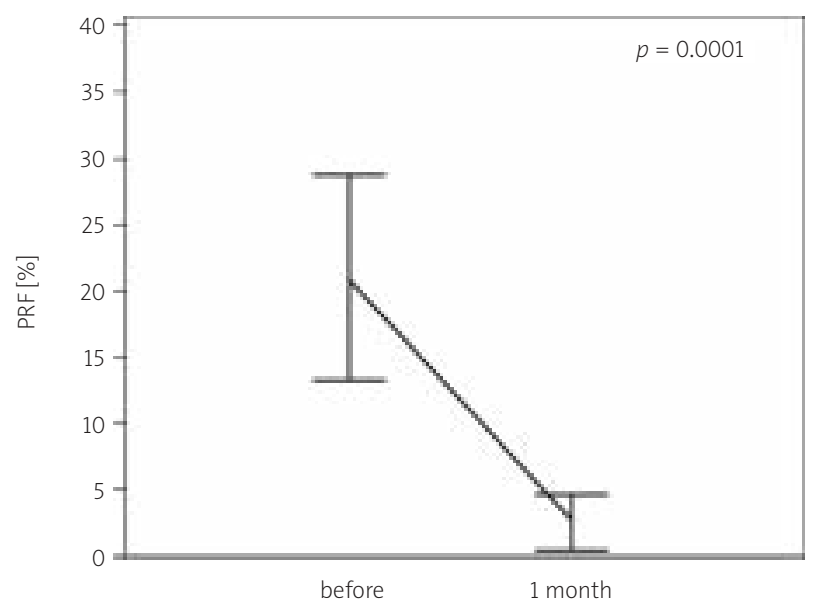

Fig. 3. Pulmonary regurgitation fraction (PRF) before and after pulmonary valve implantation in patients with significant pre-procedural pulmonary regurgitation. Error bars represent standard deviation Ryc. 3. Frakcja niedomykalności płucnej (PRF) przed i po zabiegu wszczepienia zastawki płucnej u chorych z istotna niedomykalnościa płucna stwierdzana przed zabiegiem. Wykres przedstawia wartości średnie i odchylenie standardowe after valve implantation was observed in 3 patients: one with severe pre-procedural PR and two with substantial RVOT calcificasions.

\section{Follow-up}

After one month further non-significant gradient reduction was observed (mean $30.4 \pm 11.2 \mathrm{~mm} \mathrm{Hg} ; p=0.22$ Bonferoni corrected). Six months (11 pts) and 1 year (10 pts) after TPVI peak RVOT gradient remained low [mean $31.1 \pm 11.9$ and $32.7 \pm 11.7 \mathrm{~mm} \mathrm{Hg}$, respectively, (ANOVA, $p=\mathrm{NS}$ )] (fig. 2. B).

Mean PRF decreased from $20.9 \pm 7.8 \%$ to $2.4 \pm 2.1 \%$ ( $p=0.0001$ ) one month after the procedure. Pulmonary regurgitation was not aggravated at 6-month and 1-year follow-up (fig. 3).

Significant decrease in right ventricular end-diastolic and end-systolic volumes $\left(1318 \pm 47.8 \mathrm{ml} / \mathrm{m}^{2}\right.$ to $115.3 \pm 40.3 \mathrm{ml} / \mathrm{m}^{2} ; p=0.002$ and $73.1 \pm 41.1 \mathrm{ml} / \mathrm{m}^{2} \mathrm{vs}$. $57.6 \pm 39.0 \mathrm{ml} / \mathrm{m}^{2} ; p=0.004$, respectively) as well as a slight improvement in RV ejection fraction (47.9 $\pm 13.0 \%$ to $53.2 \pm 15.2 \%$; $p=0.07$ ) were observed one month after TPVI (fig. 4). No stent fractures were seen.

The NYHA class improved from a median of II to I $(p<0.0001)$ one month after the Melody valve implantation. No patient deteriorated during one year follow-up. Objective parameters of exercise capacity with the use of cardiopulmonary exercise testing before the procedure were not assessed systematically. In a small group of 8 patients, who completed one-year observation and had cardiopulmonary exercise test performed before TPVI, mean value of $\mathrm{MVO}_{2}$ increased from $20.44 \pm 5.93 \mathrm{ml} / \mathrm{kg} / \mathrm{min}$ before the procedure to 25.19 $\pm 4.72 \mathrm{ml} / \mathrm{kg} / \mathrm{min}$ after one year of observation $(p=\mathrm{NS})$. 


\section{Disscussion}

We demonstrated that TPVI could be performed successfully, with no complications in patients with RVOT dysfunction after surgical correction of various CHD. Although our report covers 17 patients, it has to be pointed out that only few centres worldwide reported larger number of patients undergoing TPVI with the use of the Melody valve and only one of them was a follow up longer [17, 22-25]. Previous studies showed excellent early and intermediate-term results, yet, not free from complications [22, 26, 27].

In our center TPVI was successfully performed in all patients without serious complications. We believe that the patients' selection was one of most important causes of that. Transvascular pulmonary valve implantation was preceded by precise evaluation of morphological requirements necessary for the anchoring of the valve. The anatomy of the RVOT was studied in detail on cine CMR images and maximal and minimal dimensions throughout the cardiac cycle were determined. A three-dimensional reconstruction of the RVOT was analyzed. In a case of any doubts, balloon sizing was performed at the time of catheterization. Though current indications for TPVI are limited to patients who have RV-to-PA conduit [29] we decided to perform the procedure in 2 patients with RVOT patch (aortic monocusp valve). The Melody valve can be dilated to a diameter of maximum $22 \mathrm{~mm}$. Patched RVOT usually are to large and do not provide secure conditions for current device implantation. However, in our 2 patients with this kind of RVOT reconstruction the narrowest diameter of the RVOT did not exceed $22 \mathrm{~mm}$. Prestenting with BMS created an artificial conduit which facilitated placing the valve. Encouraging results of extended application of TPVI for patched RVOT have been recently published by Momenah et al. [23].

Spectacular RVOT gradient reduction with concomitant restoration of valve competence led in our patients to significant decrease in RV size and improvement in RV function measured as RVEF. Previous studies provided conflicting results concerning RV function after TPVI.

Fig. 4. Changes in right ventricular size and function before and after pulmonary valve implantation. Error bars represent standard deviation. A - right ventricular end-diastolic volume (RVEDV); B - right ventricular end-systolic volume (RVESV); $\mathrm{C}$ - right ventricular ejection fraction (RVEF)

Ryc. 4. Zmiana wymiarów i czynności prawej komory miesiąc po wszczepieniu zastawki płucnej w porównaniu z danymi sprzed zabiegu. $A$-objętość końcoworozkurczowa prawej komory (RVEDV); B - objętość końcowoskurczowa prawej komory (RVESV); C - frakcja wyrzutu prawej komory (RVEF). Wykresy przedstawiają wartości średnie i odchylenie standardowe
Coats et al. demonstrated that RVEF did not change in patients with predominat PR but improved substantially in patients with predominant RVOT obstruction $[19,20]$. Since in our study the majority of patients had predominat RVOT obstruction or mixed lesions we demonstrated significant improvement in RV systolic function.

Unlike most studies published previously reporting the use of the Melody valve [22, 26, 27] we observed no stent

A

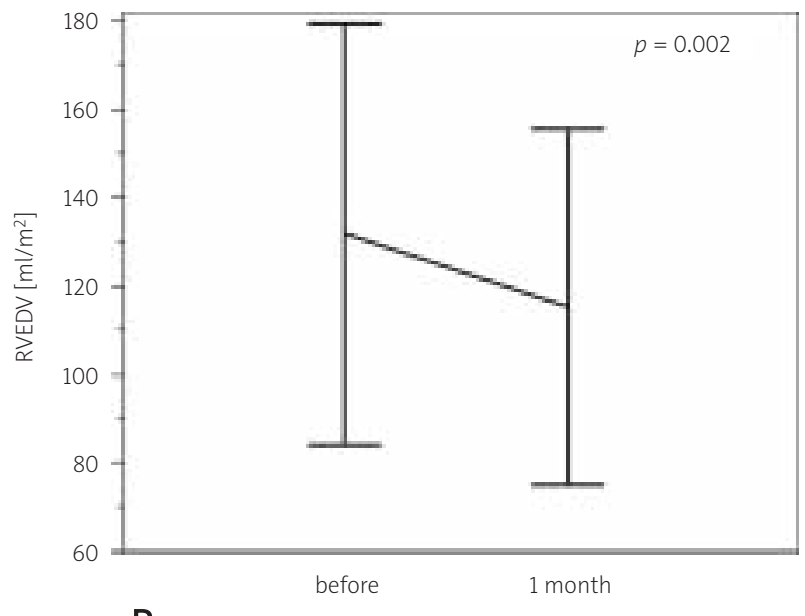

B

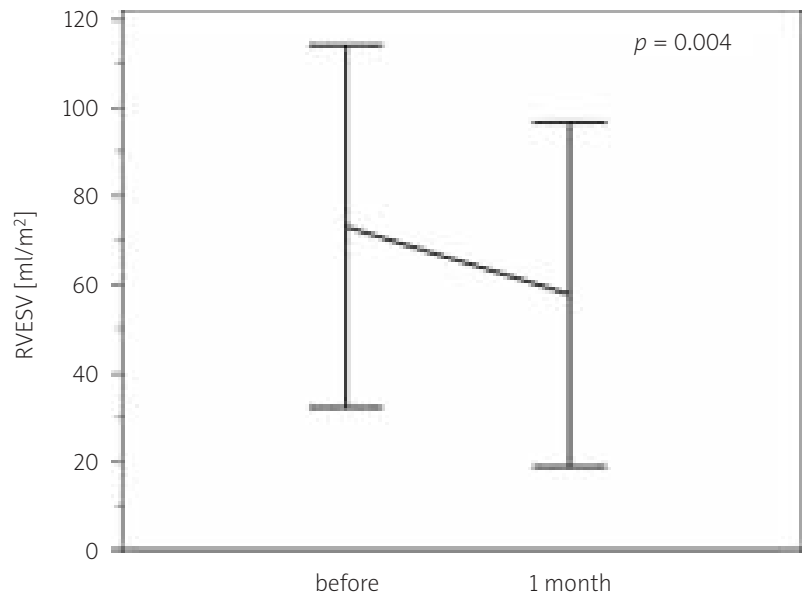

C

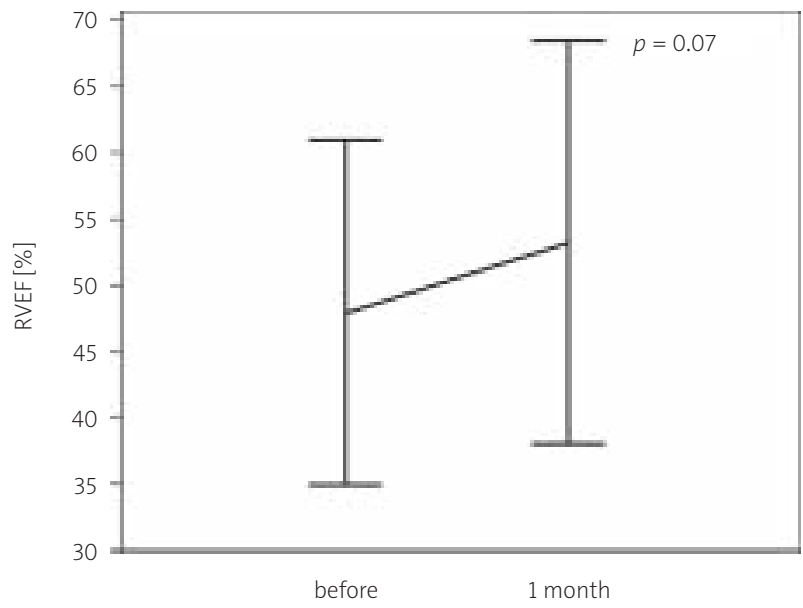


fractures during 6 and 12 month follow-up. In the study by Nordmeyer most stent fractures occurred in the first 400 days with a substantial number during first 180 days after implantation [26]. Moreover, Zahn et al. reported stent fracture rate of $28 \%$ during 6 -month follow-up [22]. It was demonstrated, that three factors were associated with risk of stent fractures: implantation into native RVOT, noncalcified RVOT and acute stent recoil following balloon deflation [26]. The Melody valve was implanted into pulmonary homograft in majority of our patients, homograft calcifications were observed in almost all patients and stent recoil in $18 \%$ patients respectively. Therefore our study population can be regarded as low risk of stent fractures. Nevertheless, we and others hypothesize that pre-stenting with BMS may act as an important protective factor against stent fractures [23, 28, 29]. This hypothesis needs to be evaluated in further studies.

Surgical implantation of RV to PA conduit can be currently performed with low early mortality both during primary repair and replacement procedure $[11,12,15,16]$. However, surgery is associated with mean hospital stay of about two weeks $[11,15]$. It is considerably longer than in the case of TPVI (average of about 3.5 days in our study). Good results, lower risk of complications, shorter hospitalization time comparing with surgery lead to better patient acceptance and promote earlier intervention before irreversible right ventricular dysfunction occurs.

\section{Conclusions}

1. Transvascular pulmonary valve implantation is an effective and safe method of non-surgical treatment for patients with RVOT conduit dysfunction.

2. Transvascular pulmonary valve implantation with the use of pre-stenting technique may be performed in selected patients with RVOT patch.

3. Routine pre-stenting with BMS may prevent stent fractures after TPVI.

4. The study showed excellent results in 10 patients after one-year follow-up.

\section{References}

1. Bonhoeffer P, Boudjemline Y, Saliba Z, et al. Percutaneous replacement of pulmonary valve in a right-ventricle to pulmonaryartery prosthetic conduit with valve dysfunction. Lancet 2000; 356 : 1403-1405.

2. Bonhoeffer P, Boudjemline $Y$, Qureshi SA, et al. Percutaneous insertion of the pulmonary valve. J Am Coll Cardiol 2002; 39: 1664-1669.

3. Khambadkone S, Coats L, Taylor A, et al. Percutaneous pulmonary valve implantation in humans: results in 59 consecutive patients. Circulation 2005; 112: 1189-1197.

4. Demkow M, Rużyłło W, Włodarska EK, et al. Non-surgical, transcatheter pulmonary valve implantation - first experience. Kardiol Pol 2009; 67: 110-114.

5. Rużyłło W, Demkow M, Włodarska EK, et al. POL-PAVTI - Polish report on transcatheter pulmonary artery valve implantation of
Melody-Medtronic prosthesis in the first 14 patients in Poland. Kardiol Pol 2009; 67: 1155-1161.

6. Warnes CA, Liberthson R, Danielson GK Jr, et al. Task Force 1: the changing profile of congenital heart disease in adult life. J Am Coll Cardiol 2001; 37: 1170-1175.

7. Moons $\mathrm{P}$, Engelfriet $\mathrm{P}$, Kaemmerer $\mathrm{H}$, et al. Delivery of care for adult patients with congenital heart disease in Europe: results from the Euro Heart Survey. Eur Heart J 2006; 27: 1324-1330.

8. Hoffman JI, Kaplan S, Liberthson RR. Prevalence of congenital heart disease. Am Heart J 2004; 147: 425-439.

9. Lloyd-Jones D, Adams RJ, Brown TM, et al. Heart disease and stroke statistics - 2010 update: a report from the American Heart Association. Circulation 2010; 121: e46-e215.

10. Trojnarska O. Cardiologic care for adult patients with congenital heart disease in Western Poland. Folia Cardiol 2006; 13: 140-146.

11. Dearani JA, Danielson GK, Puga FJ, et al. Late follow-up of 1095 patients undergoing operation for complex congenital heart disease utilizing pulmonary ventricle to pulmonary artery conduits. Ann Thorac Surg 2003; 75: 399-411.

12. Boethig D, Goerler H, Westhoff-Bleck M, et al. Evaluation of 188 consecutive homografts implanted in pulmonary position after 20 years. Eur J Cardiothorac Surg 2007; 32: 133-142.

13. Luk A, Butany J, Erlich SA, et al. Long-term morphological changes in a cryopreserved pulmonary valve homograft. Can J Cardiol 2007; 23: 817-819.

14. Oosterhof T, Meijboom FJ, Vliegen HW, et al. Long-term follow-up of homograft function after pulmonary valve replacement in patients with tetralogy of Fallot. Eur Heart J 2006; 27: 1478-1484.

15. Loukanov T, Sebening C, Springer W, et al. Replacement of valved right ventricular to pulmonary artery conduits: an observational study with focus on right ventricular geometry. Clin Res Cardiol 2008; 97: 169-175.

16. Mohammadi S, Belli E, Martinovic I, et al. Surgery for right ventricle to pulmonary artery conduit obstruction: risk factors for further reoperation. Eur J Cardiothorac Surg 2005; 28: 217-222.

17. Lurz P, Coats L, Khambadkone S, et al. Percutaneous pulmonary valve implantation: impact of evolving technology and learning curve on clinical outcome. Circulation 2008; 117: 1964-1972.

18. Indications, Contraindications, Warnings, Precautions and Adverse Events: Melody ${ }^{\circledR}$ Transcatheter Pulmonary Valve and Ensemble ${ }^{\circledR}$ Transcatheter Delivery System - Medtronic, Inc International Section. Available at: http://www.medtronic.com/intl/melody/ melody_warn.html. Accessed 2010-01-16.

19. Coats L, Khambadkone S, Derrick G, et al. Physiological and clinical consequences of relief of right ventricular outflow tract obstruction late after repair of congenital heart defects. Circulation 2006; 113: 2037-2044.

20. Coats L, Khambadkone S, Derrick G, et al. Physiological consequences of percutaneous pulmonary valve implantation: the different behaviour of volume- and pressure-overloaded ventricles. Eur Heart J 2007; 28: 1886-1893.

21. Sridharan S, Coats L, Khambadkone S, et al. Images in cardiovascular medicine. Transcatheter right ventricular outflow tract intervention: the risk to the coronary circulation. Circulation 2006; 113: e934-5.

22. Zahn EM, Hellenbrand WE, Lock JE, et al. Implantation of the melody transcatheter pulmonary valve in patients with a dysfunctional right ventricular outflow tract conduit early results from the u.s. Clinical trial. J Am Coll Cardiol 2009; 54: 1722-1729.

23. Momenah TS, El Oakley R, Al Najashi K, et al. Extended application of percutaneous pulmonary valve implantation. J Am Coll Cardiol 2009; 53: 1859-1863. 
24. Romeih S, Kroft LJ, Bokenkamp R, et al. Delayed improvement of right ventricular diastolic function and regression of right ventricular mass after percutaneous pulmonary valve implantation in patients with congenital heart disease. Am Heart J 2009; 158: 40-46.

25. Moiduddin N, Asoh K, Slorach C, et al. Effect of transcatheter pulmonary valve implantation on short-term right ventricular function as determined by two-dimensional speckle tracking strain and strain rate imaging. Am J Cardiol 2009; 104: 862-867.

26. Nordmeyer J, Khambadkone S, Coats L, et al. Risk stratification, systematic classification, and anticipatory management strategies for stent fracture after percutaneous pulmonary valve implantation. Circulation 2007; 115: 1392-1397.
27. Nordmeyer J, Coats L, Lurz P, et al. Percutaneous pulmonary valvein-valve implantation: a successful treatment concept for early device failure. Eur Heart J 2008; 29: 810-815.

28. Demkow M, Biernacka EK, Śpiewak M, et al. Percutaneous pulmonary valve implantation preceded by routine pre-stenting with a bare metal stent. Catheter Cardiovasc Interv 2010 Jul 2. [Epub ahead of print]

29. Lurz P, Nordmeyer J, Muthurangu V, et al. Comparison of bare metal stenting and percutaneous pulmonary valve implantation for treatment of right ventricular outflow tract obstruction: use of an x-ray/magnetic resonance hybrid laboratory for acute physiological assessment. Circulation 2009; 119: 2995-3001. 